\title{
PENGARUH HARGA SAHAM, VOLUME PERDAGANGAN, DAN FREKUENSI PERDAGANGAN TERHADAP BID-ASK SPREAD
}

\author{
Rahma Nurul Khoirayanti ${ }^{1}$, Hari Sulistiyo ${ }^{2}$ \\ 1,2Universitas Singaperbangsa Karawang, Kabupaten Karawang, Indonesia \\ Email: rahmarayanti@gmail.com
}

\begin{abstract}
This study aims to determine the effect of stock prices, trading volume and trading frequency on the bid-ask spread of companies listed in the LQ-45 Index. This type of research is descriptive verification research. The population of this study is all companies listed on the Indonesian stock exchange (BEI). The research sample was selected using purposive sampling method in order to obtain 10 sample companies. Data analysis using multiple regression analysis. The results showed that the stock price had no effect on the bid-ask spread, while the volume and frequency of trading had an effect on the bid-ask spread. In addition, if the independent variable simultaneously affects the dependent variable. The implication of this research is that companies really need to pay attention to the level of trading volume and trading frequency because these ratios are very influential on investors' perceptions.
\end{abstract}

Keywords: bid-ask spread, stock price, trading frequency, trading volume activity

\section{ABSTRAK}

Penelitian ini bertujuan untuk mengetahui pengaruh harga saham, volume perdagangan dan frekuensi perdagangan terhadap bid-ask spread pada perusahaan terdaftar dalam Indeks LQ-45. Jenis penelitian ini adalah penelitian deskriptif verifikatif. Populasi penelitian ini adalah seluruh perusahaan yang terdaftar dalam bursa efek Indonesia (BEI). Sampel penelitian dipilih menggunakan metode purposive sampling sehingga diperoleh 10 sampel perusahaan. Analisis data menggunakan analisis regresi berganda. Hasil penelitian menunjukkan bahwa harga saham tidak berpengaruh terhadap bid-ask spread sedangkan volume dan frekuensi perdagangan berpengaruh terhadap bid-ask spread. Selain itu, jika secara simultan variabel independen berpengaruh terhadap variabel dependen. Implikasi dari penelitian ini bahwa perusahaan sangat perlu memperhatikan tingkat volume perdagangan dan frekuensi perdagangan karena rasio tersebut sangat berpengaruh terhadap persepsi investor.

Kata kunci: bid-ask spread, frekuensi perdagangan, harga saham, volume perdagangan

\section{KETERANGAN ARTIKEL}

Riwayat Artikel: diterima: 13 Agustus 2020; direvisi: 14 Desember 2020; disetujui: 21 Desember 2020

Klasifikasi JEL: G10

Cara Mensitasi: Khoirayanti, R. N. dan Sulistiyo, H. (2020). Pengaruh Harga Saham, Volume Perdagangan, dan Frekuensi Perdagangan terhadap Bid-Ask Spread. JIAFE (Jurnal IImiah Akuntansi Fakultas Ekonomi), 6(2), 231-240. https://doi.org/10.34204/jiafe.v6i2.2305

Copyright@2020. JIAFE (Jurnal Akuntansi Ilmiah Fakultas Ekonomi) Universitas Pakuan

\section{PENDAHULUAN}

Perkembangan pasar modal dapat dilihat untuk menilai kemajuan perekonomian suatu negara. Dalam pasar modal, istilah investasi bukanlah kata yang asing saat kita dengar, investasi diharapkan mendatangkan keuntungan dimasa yang akan datang. Besar kecilnya investasi mempengaruhi peningkatan pertumbuhan ekonomi di suatu negara. Para investor perlu mengetahui informasi yang berkaitan dengan dinamika harga saham agar bisa mengambil keputusan tentang saham yang layak untuk dipilih. 
Tahun 2017, banyak pihak yang menyarankan investor pemula sebaiknya memilih saham-saham LQ45 di pasar modal. Sebab saham-saham di LQ45 dianggap aman dalam berinvestasi. Namun, menurut Pengamat Pasar Modal Satrio Utomo, sahamsaham di LQ45 sebenarnya tidak cocok untuk direkomendasikan kepada investor pemula. Sebab karakter saham yang termasuk dalam indeks LQ45 berdasarkan aktifnya pergerakan saham tersebut baik menguat atau melemah akan tetap liquid (Sugianto, 2017). Banyak saham-saham di LQ45 yang sudah tidur lama di level Rp50 tiba-tiba menguat hingga puluhan persen dalam satu hari. Hal itu tentu menggiurkan bagi pelaku pasar. Namun membeli saham tersebut tentu beresiko tinggi. Sebab saham-saham tersebut seperti zombie yang tiba-tiba bangkit dan rawan untuk kembali tidur.

Selama periode penelitian 2015 hingga 2018 Indeks LQ45 mengalami penurunan signifikan secara terus menerus. Diawali pada tahun 2015, Indeks LQ45 mengalami penurunan sebesar $0,23 \%$ dari tahun sebelumnya menjadi 844,72 . Kemudian pada tahun 2016, Indeks LQ45 mengalami penurunan sebesar 0,33\% menjadi 884,61.
Lalu pada tahun 2017, Indeks LQ45 mengalami penurunan sebesar $0,45 \%$ menjadi 936 . Dan terakhir pada tahun 2018 mengalami penurunan sebesar 0,80\% menjadi 982,85.

Dalam melaksanakan aktivitas perdagangan saham, pada umumnya investor membutuhkan informasi dalam melaksanakan aktivitas perdagangan saham. Salah satu jenis informasi tersebut adalah besaran biaya transaksi dalam mekanisme perdagangan. Biaya transaksi dimaninvestasikan oleh besaran bid-ask spread. Besaran bid-ask spread pada dasarnya memiliki elemen informasi asimetri. Oleh karenanya, pelaku pasar yang uninformed menghadapi risiko jika bertransaksi dengan pelaku pasar yang informed. Untuk meminimalkan risiko tersebut, maka pelaku pasar melebarkan bidask spread (Nainggolan dan Silalahi, 2016). Besaran bid-ask spread merupakan proksi untuk menentukan likuiditas pasar. Likuiditas pasar saham dapat dijelaskan secara langsung maupun secara tidak langsung. Pengukuran likuiditas secara langsung dapat diketahui melalui besaran bid-ask spread, sedangkan pengukuran likuiditas secara tidak langsung dapat dijelaskan melalui hubungan antara bidask spread dengan volume perdagangan.

Tabel 1. Rata-rata Bid-Ask Spread, Harga Saham, Volume Perdagangan, dan Frekuensi Perdagangan periode 2015-2018

\begin{tabular}{|c|c|c|c|c|}
\hline Keterangan & 2015 & 2016 & 2017 & 2018 \\
\hline Bid-Ask Spread & 2,53 & 3,43 & 2,01 & 3,43 \\
\hline Harga Saham & 15223,08 & 10456,79 & 7239,17 & 6489,72 \\
\hline Volume Perdagangan & 490580,32 & 599233,11 & 524280,67 & 640776,08 \\
\hline Frekuensi Perdagangan & 60321,41 & 70783,30 & 57585,50 & 77050,27 \\
\hline
\end{tabular}

Sumber: data primer yang diolah, 2020.

Tabel 1 menunjukkan arah perkembangan bid-ask spread dalam indeks LQ-45 dari tahun 2015-2018. Pada tahun 2015 rata-rata bid-ask spread perusahaan bernilai 2,53. Kemudian mengalami kenaikan pada tahun 2016 rata-rata bid-ask spread perusahaan berada pada angka 3,43. Kemudian pada tahun 2017 mengalami penurunan menjadi 2,01. Namun, pada tahun 2018 bid-ask spread mengalami peningkatan kembali menjadi 3,43. Berdasarkan data tersebut, dapat kita simpulkan bahwa bid-ask spread dari tahun 2015 hingga 2018 bersifat fluktuatif.

Harga saham yang terjadi di pasar bursa pada saat tertentu yang ditentukan oleh 
pelaku pasar dan ditentukan oleh permintaan dan penawaran saham yang bersangkutan di pasar modal. Penurunan permintaan saham dapat disebabkan karena investor menilai harga saham terlalu tinggi, sehingga para investor beralih kepada saham perusahaan lain. Untuk menghidari munculnya kejadian tersebut, maka perusahaan harus berupaya mengembalikan harga saham pada jangkauan tertentu. Dengan kata lain perusahaan harus menurunkan harga saham yang dinilai terlalu tinggi (Patoni dan Lasmana, 2018).

Volume perdagangan saham digunakan untuk melihat reaksi pasar pada informasi melalui pengamatan perubahan volume perdagangan di pasar modal. Para pelaku pasar cenderung kurang menyukai transaksi pada saham yang kurang liquid, sehingga hal ini akan menurunkan tekanan pada spreadnya (Wahyuliantini dan Suarjaya, 2015). Dari tabel tersebut kita dapat melihat arah perkembangan Volume Perdagangan dan Frekuensi Perdagangan dalam indeks LQ-45 dari tahun 2015-2018. Dimulai pada tahun 2015, kemudian mengalami kenaikan pada tahun 2016. Lalu pada tahun 2017 mengalami penurunan. Namun pada tahun 2018 bid-ask spread mengalami peningkatan kembali. Kondisi frekuensi perdagangan ini sama persis dengan kondisi Volume Perdagangan. Hal ini di karenakan Frekuensi Perdagangan berbanding lurus dengan Volume Perdagangan, semakin besar Frekuensi Perdagangan maka semakin semakin tinggi Volume Perdagangan yang dihasilkan.

Dengan melihat berapa kali atau frekuensi jumlah saham yang di perdagangkan, dan berapa banyak atau volume saham lembar saham yang diperdagangkan maka dapat dilihat bahwa saham tersebut diminati atau tidak oleh investor. Dengan meningkatnya jumlah frekuensi dan volume transaksi perdagangan, yang biasanya disebabkan permintaan yang tinggi maka harga saham akan terdorong naik sehingga return saham juga akan meningkat.
Dalam aktivitas bursa efek ataupun pasar modal, aktivitas volume perdagangan saham dan frekuensi perdagangan saham merupakan salah satu elemen yang menjadi salah satu bahan untuk melihat reaksi pasar terhadap sebuah informasi yang masuk pada pasar modal.

Tujuan dari penelitian ini yaitu ingin mengetahui pengaruh variabel independen (Harga Saham, Volume Perdagangan dan Frekuensi Perdagangan) terhadap variabel dependen (Bid-Ask Spread) baik secara parsial maupun secara simultan.

\section{KAJIAN LITERATUR DAN PENGEMBANGAN HIPOTESIS}

\section{Harga Saham dan Bid-Ask Spread}

Pengetahuan tentang bid-ask spread dirasa perlu diketahui bagi investor terutama yang mengharapkan dapat memperoleh capital gain, karena bid-ask spread dianggap sebagai salah satu komponen biaya dalam perdagangan saham (Patoni dan Lasmana, 2018). Terdapat beberapa faktor yang mempengaruhi bid-ask spread, yang pertama adalah harga saham. Ketika harga saham tinggi maka dapat dikatakan saham tersebut aktif diperdagangkan. Harga saham yang terlalu tinggi akan membuat suatu saham tidak liquid atau sulit di perdagangkan. Ketika harga saham tinggi, berarti saham aktif diperdagangkan, sehingga dealer tidak akan menyimpan saham tersebut dalam jangka waktu terlalu lama. Hal ini akan berdampak pada tingkat bid-ask spread dan menurunnya biaya kepemilikan yang pada akhirnya menyebabkan semakin tingginya harga saham dan semakin kecilnya bid-ask spread. Bid-ask spread berbanding lurus dengan harga saham, yang berarti, ketika harga saham tinggi, maka bid-ask spreadnya juga semakin besar (Rahmawati, 2011). Pernyataan tersebut didukung penelitian yang dilakukan Rosdiana (2019) dan Perdana dan Kristanti (2014) yang menyatakan jika harga saham berpengaruh terhadap bid-ask spread. 
$\mathrm{H}_{1}$ : Harga Saham berpengaruh terhadap BidAsk Spread

\section{Volume Perdagangan dan Bid-Ask Spread}

Volume perdagangan menggambarkan aktivitas jumlah saham yang diperdagangkan di pasar modal. Volume perdagangan yang kecil memperlihatkan ketidakyakinan investor akan suatu saham yang sedang diperdagangkan. Begitupun sebaliknya, volume perdagangan yang besar menunjukan bahwa saham tersebut diminati oleh para investor. Volume perdagangan saham digunakan untuk melihat reaksi pasar pada informasi melalui pengamatan perubahan volume perdagangan di pasar modal. Para pelaku pasar cenderung kurang menyukai transaksi pada saham yang kurang liquid, sehingga hal ini akan menurunkan tekanan pada spread-nya (Wahyulianti dan Suarjaya, 2016). Naiknya volume perdagangan merupakan kenaikan aktivitas jual beli para investor di bursa yang memberikan pengaruh terhadap tingkat bid ask spread suatu saham (Shobriati dkk,2013). Pernyataan tersebut didukung penelitian yang dilakukan Rosdiana (2019), Kurniawan dan Afriyenti (2019), Perdana dan Kristanti (2014), Ulfaniza dan Listyaningsih (2017) dan Alkusani, dkk (2020) yang menyatakan volume Perdagangan berpengaruh terhadap Bid-Ask Spread.

$\mathrm{H}_{2}$ : Volume Perdagangan berpengaruh terhadap Bid-Ask Spread.

\section{Frekuensi Perdagangan dan Bid-Ask Spread}

Perlu juga memperhatikan pengaruh frekuensi perdagangan sebuah sekuritas terhadap bid- ask spread. Dengan melihat berapa kali atau frekuensi jumlah saham yang diperdagangkan, maka dapat dilihat apakah saham tersebut diminati atau tidak oleh para investor. Semakin meningkat volume penawaran dan permintaan suatu saham, semakin besar pengaruhnya terhadap fluktuasi pergerakan harga saham di bursa, dan semakin meningkatnya volume perdagangan saham menunjukkan semakin diminatinya saham tersebut oleh masyarakat sehingga akan membawa pengaruh terhadap naiknya frekuensi perdagangan saham tersebut (Wiharno dan Rahayu, 2018). Meningkatnya jumlah frekuensi transaksi perdagangan, yang biasanya disebabkan permintaan yang tinggi maka harga saham akan terdorong naik sehingga return saham juga akan meningkat. Dalam aktivitas bursa efek ataupun pasar modal, aktivitas frekuensi perdagangan saham merupakan salah satu elemen yang menjadi salah satu bahan untuk melihat reaksi pasar terhadap sebuah informasi yang masuk pada pasar modal (Silviyani, dkk., 2014). Pernyataan tersebut didukung penelitian yang dilakukan Patoni dan Lasmana (2018) dan Alkusani, dkk (2020) yang menyatakan Frekuensi Perdagangan berpengaruh terhadap Bid-Ask Spread.

$\mathrm{H}_{3}$ : Frekuensi Perdagangan berpengaruh terhadap Bid-Ask Spread.

$\mathrm{H}_{4}$ : Harga Saham, Volume Perdagangan dan Frekuensi Perdagangan berpengaruh terhadap Bid Ask Spread. 
$\mathrm{H}_{4}$

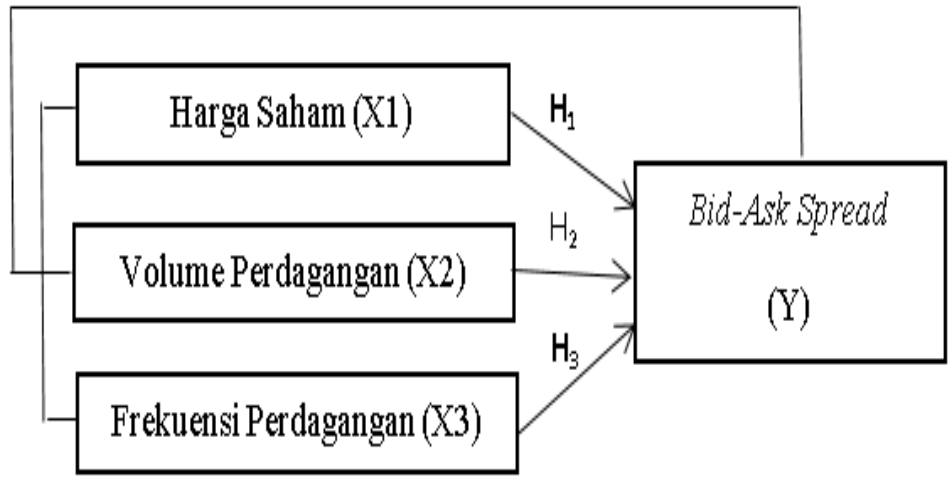

Gambar 1. Kerangka Pemikiran

\section{METODE PENELITIAN}

Penelitian ini merupakan penelitian deskriptif kuantitatif. Populasi penelitian ini adalah selutih perusahaan yang terdaftar di Bursa Efek Indonesia dan tercatat dalam Indeks LQ45 periode 2015-2018. Sampel penelitian ini dipilih menggunakan metode purposive sampling yang memenuhi kriteria, diantaranya adalah perusahaan yang memiliki kelengkapan data variabel, didapatkan 10 perusahaan. Analisis data menggunakan analisis regresi berganda.

\section{Operasionalisasi Variabel}

Harga saham yang digunakan adalah harga saham pada saat penutupan perbulan yang kemudian dijumlah selama satu tahun dan kemudian dirata-ratakan.

$$
\text { Harga Saham }=\text { Avg. }(\text { Closing Price })
$$

Volume perdagangan yang digunakan adalah volume perdagangan pada saat penutupan perbulan yang kemudian dijumlah selama satu tahun dan kemudian dirataratakan.

$$
\begin{aligned}
& \text { Volume } \\
& =\text { Avg. (Volume Perdagangan) }
\end{aligned}
$$

Frekuensi perdagangan yang digunakan adalah frekuensi perdagangan pada saat penutupan perbulan yang kemudian dijumlah selama satu tahun dan kemudian dirataratakan.

$$
\begin{aligned}
& \text { Frequency } \\
& =\text { Avg.(Freq.Perdagangan) }
\end{aligned}
$$

Berikut adalah rumusan untuk mendapatkan nilai bid-ask spread:

$$
B A S=\frac{\left(A s k_{i t}-B i d_{i t}\right)}{\frac{1}{2}\left(A s k_{i t}+B i d_{i t}\right)} \times 100
$$

\section{HASIL DAN PEMBAHASAN}

\section{Uji Determinasi (R2)}

Analisa koefisien determinasi digunakan untuk melihat seberapa besar variabel independen (X) berpengaruh terhadap variabel dependen (Y) yang dinyatakan dalam presentase. Koefisien determinasi juga digunakan untuk menjelaskan model regresi dalam variabel dependen. Koefisien determinasi mempunyai nilai antara 0-1. Jika nilai koefisien determinasi mendekati 1, maka akan semakin besar pengaruh variabel independen terhadap variabel dependen, begitu juga sebaliknya. Berikut adalah hasil dari uji koefisien determinasi. 
Rahma Nurul Khoirayanti: Pengaruh Harga Saham ...

Tabel 2. Hasil Uji Koefisien Determinasi

\begin{tabular}{ccccc}
\hline Model & $\mathbf{R}$ & $\begin{array}{c}\mathbf{R} \\
\text { Square }\end{array}$ & $\begin{array}{c}\text { Adj. } \mathbf{R} \\
\text { Square }\end{array}$ & $\begin{array}{c}\text { Durbin- } \\
\text { Watson }\end{array}$ \\
\hline 1 & 0,578 & 0,334 & 0,278 & 2,062
\end{tabular}

Berdasarkan hasil perhitungan tabel diatas, dapat diketahui bahwa nilai R Square sebesar 0,334 atau 33,4\%. Hal ini menunjukkan bahwa variabel yang diteliti yaitu Harga Saham, Volume Perdagangan dan Frekuensi Perdagangan berpengaruh terhadap Bid-Ask Spread sebesar 33,4\%. Sedangkan sisanya yaitu $66,6 \%$ dipengaruhi oleh variabel lain yang tidak diteliti dalam penelitian ini atau disebut sebagai variabel pengganggu.

\section{Uji F}

Hasil pengujian untuk menguji pengaruh semua variabel independen terhadap variabel dependen adalah sebagai berikut.

Tabel 3. Hasil Uji Secara Simultan (Uji F)

\begin{tabular}{c|c|c}
\hline Model & $F$ & Sig. \\
\hline 1 & 6,009 & 0,002 \\
\hline
\end{tabular}

Tabel 3 menunjukkan hasil pengujian secara simultan, sehingga diperoleh nilai Fhitung sebesar 6,009. Adapun nilai Ftabel pada tingkat signifikasi $5 \%$ dan derajat kebebasan df1 (variabel-1) $=(4-1)=3$ dan df2 $(n-k-1)=(40-3-$ 1) $=36$ maka Ftabel yaitu $(3 ; 36)=2,87$. Nilai Fhitung dan Ftabel. Selanjutnya dibandingkan, sehingga diperoleh nilai 6,009 $>2,87$ atau Fhitung $>$ Ftabel. Nilai signifikasi sebesar 0,002 < 0,05 sehingga $\mathrm{H}_{0}$ ditolak dan $\mathrm{Ha}$ diterima. Dengan demikian dapat disimpulkan bahwa terdapat pengaruh signifikan variabel independen Harga Saham, Volume Perdagangan, dan Frekuensi Perdagangan secara bersama-sama terhadap Bid-Ask Spread.

\section{Uji t}

Hasil pengujian untuk menguji masing-masing variable independen terhadap variable dependen dengan taraf nyata 0,05 adalah sebagai berikut.

Tabel 4. Hasil Uji Secara Parsial (Uji t)

\begin{tabular}{llcc}
\hline \multicolumn{1}{c}{ Model } & $\mathbf{t}$ & Sig. \\
\hline 1 & Harga Saham & $-0,849$ & 0,401 \\
\cline { 2 - 3 } & $\begin{array}{l}\text { Volume } \\
\text { Perdagangan }\end{array}$ & -3876 & 0,000 \\
\hline & & \\
\hline $\begin{array}{l}\text { Frekuensi } \\
\text { Perdagangan }\end{array}$ & 3,111 & 0,004 \\
\hline
\end{tabular}

Harga saham dengan nilai $t_{\text {hitung }}$ yang diperoleh sebesar $-0,849$, sehingga nilai $t_{\text {hitung }}<$ $t_{\text {tabel. }}$ Serta nilai signifikasi sebesar 0,401 > 0,05 . Maka, $H_{0}$ diterima dan $H_{a}$ ditolak. Artinya, secara parsial, Harga Saham tidak berpengaruh terhadap Bid-Ask Spread. Volume perdagngan dengan nilai thitung yang diperoleh sebesar $-3,876$, sehingga nilai $t_{\text {hitung }}>$ $t_{\text {tabel, }}$ serta nilai signifikasi sebesar 0,000< 0,05. Maka, $H_{0}$ ditolak dan $H_{a}$ diterima, Artinya, secara parsial, Volume Perdagangan berpengaruh negatif signifikan terhadap BidAsk Spread. Frekuensi Perdagangan dengan nilai thitung yang diperoleh sebesar 3,111, sehingga nilai $t_{\text {hitung }}>t_{\text {tabel, }}$, serta nilai signifikasi sebesar 0,004 $<0,05$. Maka, $\mathrm{H}_{0}$ ditolak dan $\mathrm{H}_{\mathrm{a}}$ diterima. Artinya, secara parsial, Frekuensi Perdagangan berpengaruh signifikan terhadap Bid-Ask Spread.

\section{Pembahasan}

Harga saham merupakan indikator keberhasilan pengelolaan perusahaan. Kenaikan harga saham yang terlalu tinggi akan menyebabkan permintaan terhadap pembelian saham tersebut mengalami penurunan begitupun sebaliknya. Penurunan permintaan tersebut dapat disebabkan karena tidak semua investor tertarik untuk membeli saham dengan harga yang terlalu tinggi, terutama bagi investor yang memiliki tingkat dana terbatas (perorangan), hal tersebut akan mengakibatkan investor akan beralih untuk membeli saham perusahaan lain. Harga saham senantiasa memberikan return tinggi sehingga 
disukai oleh investor sehingga broker atau dealer tidak perlu memegang saham tersebut terlalu lama karna akan menurunkan biaya pemilikan saham yang berarti mempersempit bid-ask spread.

Variabel harga saham pada penelitian ini tidak mempunyai pengaruh terhadap BidAsk Spread. Hal ini menunjukkan bahwa keputusan investor dalam menahan atau melepas saham yang dimilikinya kurang memperhatikan variabel harga saham. Karena investor lebih memperhatikan faktor lain. Dengan demikian rencana emisi efek oleh perusahaan besar yang dapat menyebabkan merosotnya harga saham-saham lain yang terdaftar di BEl tidak menyebabkan investor menahan sahamnya lebih lama. Penelitian yang dilakukan ini menerima teori dan sejalan dengan penelitian yang dilakukan oleh Ulfaniza, dkk (2017) yang menyatakan bahwa Harga Saham tidak berpengaruh terhadap BidAsk Spread.

Nilai signifikansi menunjukkan volume perdagangan mempengaruhi bid-ask spread. Artinya, jika volume perdagangan mengalami kenaikan, maka bid-ask spread juga meningkat. Meningkatnya volume perdagangan akan menyebabkan saham menjadi semakin likuid, sehingga dealer tidak perlu menyimpan saham terlalu lama. Tanda negative koefisien regresi volume perdagangan saham menunjukkan bahwa volume perdagangan saham yang besar merupakan suatu indikasi saham tersebut aktif di perdagangkan, sehingga dealer tidak perlu terlalu lama menyimpan saham. Dealer yang berinvestasi jangka pendek hanya ingin mendapatkan capital gain, yang menyebakan jangka waktu dealer menyimpan saham berkurang. Hal ini akan menurunkan biaya kepemilikan saham sehingga memperkecil nilai bid-ask spread saham tersebut dan sebaliknya. Hasil penelitian ini sejalan dengan hasil penelitian yang dilakukan oleh Hamidah (2018) yang menyatakan bahwa Volume
Perdagangan Saham berpengaruh negatif signifikan terhadap bid-ask spread.

Frekuensi perdagangan saham adalah berapa kali transaksi saham diperjualbelikan. Hal ini menunjukkan bahwa semakin besar frekuensi perdagangan maka semakin semakin tinggi volume perdagangan yang dihasilkan. Sehingga dapat dikatakan bahwa saham tersebut diminati oleh para investor. Pada saat frekuensi meningkat, kemungkinan dealer akan mengubah posisi kepemilikan sahamnya atau dengan kata lain dealer tidak perlu memegang saham terlalu lama sehingga menurunkan biaya kepemilikan dan menurunkan spread. Penelitian yang dilakukan ini menolak teori dan tidak sejalan dengan penelitian yang dilakukan oleh Patoni dan Lasmana (2018) yang menyatakan bahwa Frekuensi Perdagangan tidak berpengaruh signifikan terhadap Bid-Ask Spread. Semakin besar frekuensi perdagangan maka semakin semakin tinggi volume perdagangan yang dihasilkan, begitupun sebaliknya. Sehingga dapat dikatakan bahwa saham tersebut diminati oleh para investor. Pada saat frekuensi meningkat, kemungkinan dealer akan mengubah posisi kepemilikan sahamnya atau dengan kata lain dealer tidak perlu memegang saham terlalu lama sehingga menurunkan biaya kepemilikan dan menurunkan spread.

\section{PENUTUP}

Tujuan dari penelitin ini adalah menguji baik secara parsial maupun simultan pengaruh dari harga saham, volume dan frekuensi perdagangan terhadap bid-ask spread. Simpulan yang dapat diambil dari penelitian ini adalah harga saham tidak berpengaruh terhadap bid-ask spread sedangkan volume perdagangan mempunyai pengaruh negatif signifikan terhadap bid-ask spread dan frekuensi perdagangan saham mempunyai pengaruh positif signifikan terhadap bid-ask spread. Kemudian secara simultan harga saham, volume perdagangan dan frekuensi 
Rahma Nurul Khoirayanti: Pengaruh Harga Saham ...

perdagangan memiliki pengaruh signifikan. Variabel yang diteliti yaitu Harga Saham, Volume Perdagangan dan Frekuensi Perdagangan berpengaruh terhadap Bid-Ask Spread BEI sebesar $33,4 \%$ dan sisanya $66,6 \%$ dipengaruhi oleh variabel lain yang tidak diteliti atau dipengaruhi oleh faktor-faktor lain diluar model.

Dengan demikian untuk para investor di Bursa Efek Indonesia sebelum mengambil keputusan dalam membeli saham disarankan untuk mempertimbangkan frekuensi perdagangan saham dan volume perdagangan yang mempunyai pengaruh signifikan terhadap bid-ask spread, karena hal ini berpengaruh kepada saham tersebut aktif diperdagangkan atau tidak. Penelitian selanjutnya diharapkan dapat menambah dan mengembangkan variabel bebas mengenai faktor-faktor yang mempengaruhi bid-ask spread, menambah tahun penelitian sehingga periode penelitian menjadi lebih panjang, menambah sektor yang diteliti sehingga sampel yang dapat diteliti bisa lebih banyak dan menambah keakuratan hasil penelitian, menambah atau meneliti indeks yang berbeda seperti Indeks Saham Syariah Indonesia (ISSI), Jakarta Islamic Index (JII), Kompas 100, Sri Kehati, dsb; serta menambah atau meneliti dengan proxy yang berbeda, misalnya menggunakan nilai logaritma natural untuk mengukur volume perdagangan saham.

\section{REFERENSI}

Alkusani, dkk. (2020). Linkage Stock Price, Trading Volume Activity, Stock Returns and Trading Frequency on Bid Ask Spread. Innovation Journal, 1(1), 28-33.

Hamidah, dkk. (2018). Pengaruh Harga Saham, Volatilitas Harga Saham, dan Volume Perdagangan Saham terhadap Bid-Ask Spread Saham pada Perusahaan Sektor Pertambangan yang Terdaftar di ISSI Periode Juni 2016-Juni 2017. JRMSI -
Jurnal Riset Manajemen Sains Indonesia, 9(1), 145-167.

Kurniawan, D. dan Afriyenti, M. (2019). Pengaruh Harga Saham, Volume Perdagangan, dan Varian Return Terhadap Bid-Ask Spread (Studi Empiris pada Perusahaan yang Melakukan Stock Split yang Terdaftar di Bursa Efek di Asia Tenggara Tahun 2018). Wahana Riset Akuntansi, 7(1).

Nainggolan, R. dan Silalahi, D. (2016). Pengaruh Volume Perdagangan Saham dan Harga Saham terhadap Bid-ask Spread Studi pada PerusahaanPerusahaan Manufaktur yang Terdaftar di Bursa Efek Indonesia. Jurnal Manajemen dan Bisnis, 16(2), 62-74.

Patoni, A. dan Lasmana, A. (2018). Pengaruh Harga Saham dan Frekuensi Perdagangan Saham terhadap Bid-Ask Spread (Studi Empiris Pada Perusahaan Manufaktur Yang Melakukan Stock Split Di Bursa Efek Indonesia Selama Periode 2009-2014. Jurnal Akunida, 1(2), 1-12.

Perdana, M. A. dan Kristanti, F. T. (2014). Pengaruh Varian Return, Harga Saham, Volume Perdagangan, Earning Per Share Terhadap Bid Ask Spread Saham Syariah (Studi Empiris Pada Perusahaan Yang Terdaftar Pada Jakarta Islamic Index Tahun 2010-2012). eProceedings of Management, 1(3), 349-370.

Rahmawati, N.A. (2011). Pengaruh Harga Saham, Trading Volume Activity, Dan Risk of Return Terhadap Bid-Ask Spread (Studi Pada Perusahaan LQ-45 Periode 2007-2009). Skripsi. Universitas Negeri Malang.

Rosdiana, D. (2019). Pengaruh Harga Saham dan Volume Perdagangan Saham terhadap Bid Ask Spread. Almana: Jurnal Manajemen dan Bisnis, 3(3), 569-575.

Silviyani, N. L., dkk. (2014). Pengaruh Likuiditas Perdagangan Saham dan Kapitalisasi Pasar terhadap Return Saham Perusahaan yang Berada pada Indeks 
LQ45 di Bursa Efek Indonesia Periode Tahun 2009-2013 (Studi Empiris Pada Perusahaan LQ45 di Bursa Efek Indonesia). E-Journal S1 Akuntansi Universitas Pendidikan Gaesha, 2(1).

Shobriati, dkk. (2013). Pengaruh Harga Saham, Volume Perdagangan Saham dan Varian Return terhadap Bid-Ask Spread di Seputar Pengumuman Stock Split. Jurnal Administrasi Bisnis. 5(2), 1-14.

Sugianto, D. 2017. Ada Saham 'Zombie', LQ45 Tak Cocok untuk Investor Pemula. Detik Finance.

https://finance.detik.com/bursa-danvalas/d-3433334/ada-saham-zombielq45-tak-cocok-untuk-investor-pemula, [diakses pada: 22 Juni 2020].

Ulfaniza, E. C. dan Listyaningsih, E. (2017). The Effect Of Trading Volume Activity, Stock
Price, Dividend, Earning Per Share, And Variance Of Return To Bid-Ask Spread (Studies in LQ-45 Company in the Indonesia Stock Exchange). Jurnal Riset Akuntansi dan Manajemen Malahayati, 6(2), 93-102.

Wahyuliantini, N. M. dan Suarjaya, A. A. G. (2015). Pengaruh Harga Saham, Volume Perdagangan Saham, dan Volatilitas Return Saham pada Bid-Ask Spread. Matrik: Jurnal Manajemen, Strategi Bisnis dan Kewirausahaan, [S.I.], 9(2), 146-155.

Wiharno, H. dan Rahayu, D. S. (2018). Determinants of Bid-Ask Spread in Indonesia: More Evidence from LQ45. Indonesian Journal Of Business And Economics, 1(1), 18-37. 
